\title{
Pengembangan Panduan Teknik Sosiodrama untuk Meningkatkan Kepercayaan Diri Siswa MTs Nurul Ulum Malang
}

\author{
Nadia Izaura Puji Pangerti*, Diniy Hidayatur Rahman, Triyono \\ Universitas Negeri Malang, Jl. Semarang No. 5 Malang, Jawa Timur, Indonesia \\ *Penulis korespondensi, Surel: izauranadia@gmail.com
}

Paper received: 2-2-2021; revised: 20-2-2021; accepted: 27-2-2021

\begin{abstract}
This study aims to develop a Sociodrama Technique Guide to Increase Self-Confidence of Students at MTs Nurul Ulum Malang. This research uses the research and development method of the Research and Development (R and D) model developed by Borg and Gall (1983) using seven out of ten steps, starting from the preliminary study and development planning guidelines to the revision of product trial results. The assessment of the material, media, and potential users will be analyzed with the type of data used, namely quantitative data and descriptive qualitative data. The assessment index for the test of experts and potential users shows very high criteria and meets the criteria very useful, very precise, very easy, and very attractive so that the product is suitable for use.
\end{abstract}

Keywords: Guidance Book; Self-Confidence; Sociodrama Technique

\begin{abstract}
Abstrak
Penelitian ini bertujuan untuk mengembangkan Panduan Teknik Sosiodrama untuk Meningkatkan Kepercayaan Diri Siswa MTs Nurul Ulum Malang. penelitian ini menggunakan metode penelitian dan pengembangan model Research and Development (R dan D) yang dikembangkan oleh Borg dan Gall (1983) dengan menggunakan tujuh langkah dari sepuluh yaitu dimulai dari studi pendahuluan dan perencanaan pengembangan panduan sampai pada revisi hasil uji coba produk. Penilaian uji ahli materi, media, dan calon pengguna akan dianalisi dengan jenis data yang digunakan yaitu data kuantitatif dan kualitatitf deskriptif. Indeks penilaian uji ahli dan calon pengguna menunjukkan kriteria sangat tinggi dan memenuhi kriteria sangat berguna, sangat tepat, sangat mudah, dan sangat menarik sehingga produk layak digunakan.
\end{abstract}

Kata kunci: Panduan; Kepercayaan Diri; Teknik Sosiodrama

\section{Pendahuluan}

Kepercayaan diri yang rendah merupakan suatu fenomena umum yang dialami oleh siswa. Setyo (2010) menunjukkan bahwa 80\% siswa SMP memiliki tingkat kepercayaan diri rendah. Fitriani (2011) juga melakukan penelitian yang menunjukkan bahwa terdapat delapan siswa MTs memiliki kepercayaan diri yang rendah. Selanjutnya, Ilangga (2014) menemukan bahwa terdapat $21,5 \%$ siswa SMP yang memiliki tingkat kepercayaan diri rendah. Penelitian lain yang dilakukan oleh Feorentika (2016) menunjukkan bahwa sekitar 13,3\% siswa SMP memiliki tingkat kepercayaan diri rendah. Penelitian lain oleh Dewi (2016) menunjukkan bahwa 16,12\% siswa SMP memiliki kepercayaan diri rendah. Demikian pula, Sholikhah (2018) juga menemukan 18 \% siswa SMP memiliki kepercayaan diri yang rendah. Dari beberapa penelitian yang sudah dipaparkan, dapat diketahui bahwa kepercayaan diri merupakan permasalahan umum yang sedang dihadapi oleh remaja terutama pada tingkat Sekolah Menengah Pertama (SMP).

Menurut Thantaway (2005) kepercayaan diri merupakan kondisi psikologis individu yang memiliki keyakinan pada diri sendiri untuk melakukan sesuatu tindakan. Definisi lain 
juga dikemukakan oleh Lauster (2002) yaitu kepercayaan diri merupakan suatu sikap atau keyakinan atas kemampuan diri sendiri sehingga dalam melakukan suatu tindakan tidak terlalu cemas, merasa bebas untuk melakukan hal-hal yang sesuai keinginan dan memiliki tanggung jawab atas perbuatannya. Selain itu, menurut Rahmat (2000) kepercayaan diri yaitu suatu kepercayaan terhadap diri sendiri yang dimiliki oleh setiap individu dalam kehidupannya dan mampu memandang dirinya secara utuh. Kepercayaan diri sangat perlu dimiliki oleh individu karena dalam lingkungan sosial ini setiap manusia bergaul satu sama lain. Seseorang yang memiliki kepercayaan diri yang rendah akan tidak bebas untuk melakukan yang diinginkannya dan untuk mencapai tujuan yang diinginkan. Berdasarkan uraian tersebut, kepercayaan diri merupakan kondisi atau keadaan dimana individu yakin terhadap diri sendiri untuk melakukan sesuatu tindakan yang diinginkan tanpa merasa panik dan cemas secara berlebihan.

Hasil-hasil penelitian terdahulu ditemukan adanya dampak negatif dari kepercayaan diri yang rendah. Menurut Luxori (2004) kurang percaya diri bisa menyebabkan seseorang cemas, tidak tenang, malas, sulit berkomunikasi, dan rendah diri. Kepercayaan diri juga mempengaruhi aspek lain dalam kehidupan individu. Hal ini didukung oleh penelitian yang dilakukan Viani (2017) menujukkan bahwa kepercayaan diri berhubungan dengan keterbukaan siswa. Jika kepercayaan diri siswa rendah maka tingkat keterbukaan siswa rendah dan sebaliknya. Penelitian lain juga dilakukan oleh Sholikhah (2018) yang menujukkan bahwa adanya hubungan antara kepercayaan diri dan prestasi belajar. Selanjutnya, Rasuly (2012) menunjukkan bahwa adanya hubungan kepercayaan diri dan penerimaan diri dengan keterampilan sosial. Berdasarkan kajian hasil penelitian di atas, dapat dilihat bahwa kepercayaan diri memiliki beberapa dampak negatif yang dapat dialami oleh siswa, antara lain yaitu dapat menyebabkan seseorang cemas, tidak tenang, sulit berkomunikasi, rendah diri, memiliki keterbukaan rendah, prestasi belajar menurun, dan memiliki penerimaan diri yang rendah dalam lingkungan sosialnya.

Berdasarkan hasil observasi dan wawancara pada 20 Juli 2020, peneliti menemukan fenomena terkait rendahnya kepercayaan diri siswa di MTs Nurul Ulum, Kota Malang. Berdasarkan observasi di sekolah tersebut ditemukan terdapat beberapa siswa yang memiliki kepercaaan diri rendah. Salah satu bentuk perilaku yang mengindikasikan kepercayaan diri rendah tersebut adalah malu bertanya ketika ada hal yang belum dipahami di kelas, malu mengungkapkan pendapat dalam forum, dan cenderung memisahkan diri dari lingkungan sosialnya di kelas. Dari pengamatan tersebut menunjukkan bahwasanya siswa MTs Nurul Ulum memiliki kepercayaan diri rendah. Hal ini diperkuat dengan hasil wawancara guru BK, yaitu kepercayaan diri siswa di MTs Nurul Ulum masih terbilang kurang karena masih banyak siswa ketika maju ke depan masih ragu-ragu, saat melakukan diskusi kelompok masih banyak kelompok yang anggotanya terlihat pasif karena kurang berani untuk mengungkapkan pendapat, dan banyak yang sering menyontek ketika ujian karena takut salah dengan jawabannya. Dari hasil observasi dan wawancara tersebut menunjukkan bahwa siswa di MTs Nurul Ulum Malang memiliki kepercayaan diri yang rendah.

Terdapat beberapa penelitian sebelumnya tentang teknik-teknik yang efektif digunakan untuk meningkatkan kepercayaan diri siswa. Sutriani (2015) menemukan bahwa teknik experiental learning efektif untuk meningkatkan kepercayaan diri. Feorentika (2016) juga melakukan penelitian yang menunjukkan bahwa teknik self-instruction efektif untuk meningkatkan kepercayaan diri. Penelitian sebelumnya juga pernah dilakukan oleh Dewi 
(2016) tentang efektivitas teknik sosiodrama untuk meningkatkan percaya diri siswa kelas VII B SMP Negeri 15 Malang. Selanjutnya, Prisnawati (2016) menemukan bahwa teknik sosiodrama efektif untuk meningkatkan kepercayaan diri siswa. Dari penjelasan penelitian di atas dapat disimpulkan bahwa terdapat beberapa teknik yang efektif digunakan untuk meningkatkan kepercayaan diri siswa.

Penelitian ini menggunakan teknik sosiodrama untuk meningkatkan kepercayaan diri karena teknik sosiodrama dirasa sesuai. Hal ini dikarenakan teknik sosiodrama memiliki beberapa kelebihan antara lain siswa dapat mengalami pengalaman drama yang diperankan, dapat mengungkapkan perasaan dan ekspresi secara langsung saat memerankan tokok pada cerita. Selain itu, teknik sosiodrama ini dapat membantu siswa dalam memahami seluk-beluk kehidupan dan suatu permasalahan khususnya permasalahan sosial atau konflik-konflik sosial (Romlah, 2018). Teknik sosiodrama ini dipilih dan disesuaikan dengan kebutuhan siswa yang di sekolah. Berdasarkan paparan tersebut, teknik sosiodrama efektif untuk meningkatkan kepercayaan diri siswa dan dapat disesuaikan dengan kondisi sekolah.

Terdapat beberapa penelitian pengembangan yang pernah dilakukan sebelumnya untuk mengintervensi kepercayaan diri. Yuono (2015) melakukan penelitian dan pengembangan media permainan monopoli untuk meningkatkan kepercayaan diri di SMP Negeri 1 Wonoayu. Kelemahan produk ini adalah membutuhkan banyak waktu karena menyesuaikan dengan permainan dan dilakukan dalam satu pertemuan. Fatimah (2015) melakukan penelitian dan pengembangan model bimbingan kelompok dengan teknik role playing untuk mengembangkan kepercayaan diri siswa. Kelemahan produk ini adalah belum adanya penjelasan setiap adegan, hanya garis besar cerita. Tristy (2015) melakukan penelitian dan pengembangan media permainan congklak untuk meningkatkan kepercayaan diri. Kelemahan dalam penelitian ini adalah pemain dalam permainan terbatas hanya dua orang sehingga siswa yang dapat praktek langsung terbatas. Siswa yang belum melakukan cenderung kurang mendapatkan pengalaman dan hanya menyimak evaluasi yang diberikan.

Berdasarkan beberapa paparan diatas dapat diketahui bahwa pengembangan yang sudah dilakukan memiliki kekurangan, oleh karena itu peneliti ingin mengembangkan produk panduan bimbingan yang diharapkan dapat menjawab kekurangan pada produk sebelumnya. Teknik sosiodrama dirasa mampu untuk meningkatkan kepercayaan diri karena sosiodrama dapat langsung mengekspresikan emosi dalam dirinya sehingga lebih memahami dirinya dalam perannya. Oleh karena itu, peneliti mengembangkan produk yang berjudul Pengembangan Panduan Teknik Sosiodrama Untuk Meningkatkan Kepercayaan Diri Siswa MTs Nurul Ulum.

\section{Metode}

Penelitian ini menggunakan desain yang dikenal dengan istilah Research and Development (R\&D) menurut Borg \& Gall (2003). Prosedur penelitian dan pengembangan menggunkan tujuh langkah tujuh yaitu (1) melakukan penelitian pendahuluan (prasurvei), (2) melakukan perencanaan, (3) mengembangkan jenis produk awal,(4) melakukan uji coba lapangan tahap awal, (5) melakukan revisi terhadap produk utama, (6) melakukan uji coba kelompok kecil dan (7) melakukan revisi terhadap produk operasional. Dari sepuluh prosedur penelitian dan pengembangan peneliti memakai tujuh prosedur karena adanya kendala waktu dan biaya. 
Uji coba produk ini terdiri atas beberapa tahap yaitu desain uji coba yang digunakan untuk memperoleh data mengenai produk yang dikembangkan, subyek uji coba adalah uji ahli materi, uji ahli materi serta uji calon pengguna, jenis data yang digunakan yaitu data kuantitatif dan data kualitatif deskriptif, instrumen pengumpulan data, dan teknik analisis data yang digunakan presantase kelayakan.

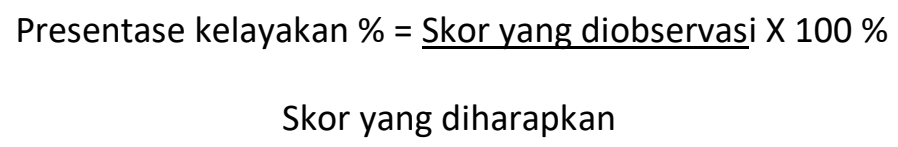

Gambar 1. Rumus Presantase

\section{Hasil dan Pembahasan}

\subsection{Hasil}

Hasil dari penelitian dan pengembangan ini yaitu panduan teknik sosiodrama untuk meningkatkan kepercayaan diri siswa yang membantu memudahkan guru BK mengintervensi kepercayaan diri rendah. Bagian pertama yaitu pendahuluan sebagai pengantar sebelum isi panduan. Bagian kedua berupa isi materi tentang kepercayaan diri dan teknik sosiodrama. Bagian ketiga berisi rincian petunjuk pelaksanaan layanan bimbingan dan kelompok yang dilaksanakan dalam enam pertemuan yang masih-masing dialokasikan waktu 40 menit pada setiap pertemuan. Panduan ini telah melewati uji ahli materi, uji ahli media, dan uji ahli calon pengguna dengan mendapat hasil data angka hasil penilaian ahli materi menunjukkan presentase validitas ahli $88,75 \%$, penilaian uji ahli media menjukkan indeks presentase $96,59 \%$, dan penilaian uji calon pengguna menujukkan indeks presentase $96,59 \%$ yang masuk dalam kategori sangat tinggi. Penilaian angka tersebut menunjukkan bahwa panduan teknik sosiodrama yang dikembangkan sesuai dengan kriteria dan memenuhi keberterimaan dalam aspek kegunaan, ketepatan, kemudahan,dan kemenarikan. Selain itu data kualitatif dari uji ahli menunjukkan ada beberapa perbaikan agar panduan teknik sosiodrama dapat sangat berguna untuk membantu guru BK dalam memberikan layanan bimbingan di sekolah.

\subsection{Pembahasan}

Produk akhir dari penelitian ini adalah panduan teknik sosiodrama untuk meningkatkan kepercayaan diri siswa MTs. Panduan ini digunakan guru BK sebagai acuan untuk memberikan layanan teknik sosiodrama di sekolah. Senada dengan itu, peneliti telah melakukan need assesment sebagai dasar pengembangan panduan teknik sosiodrama agar sesuai dengan kebutuhan siswa di MTs Nurul Ulum Malang.

Panduan teknik sosiodrama ini terdiri dari 4 bagian antara lain bagian (1) pendahuluan, (2) penjelasan teknik sosiodrama untuk meningkatkan kepercayaan diri, (3) petunjuk pelaksanaan bimbingan,dan (4) RPL teknik sosiodrama. Bagian 1 pendahuluan berisi tentang rasional dan tujuan panduan teknik sosiodrama. Rasional ini merupakan penjabaran fenomena yang ada di sekolah terkait kepercayaan diri dan pelaksanaan teknik sosiodrama sebagai upaya untuk meningkatkan kepercayaan diri siswa MTs. Bagian 2 penjelasan teknik sosiodrama dan kepercayaan diri yang berisi materi kepercayaan diri dan 
teknik sosiodrama. Materi ini disusun berdasarkan kajian yang dilakukan peneliti berdasarkan sumber dari jurnal dan buku. Bagian 3 petunjuk pelaksanaan bimbingan yaitu petunjuk penggunaaan panduan teknik sosiodrama yang terdiri dari petunjuk umum, sasaran pengguna, peserta layanan, jumlah peserta layanan, strategi intervensi, rincian waktu pelaksanaan, dan peran konselor serta peran siswa. Bagian 4 RPL teknik sosiodrama adalah rencana pelaksanaan konseling yang terdiri dari enam kali pertemuan. RPL bimbingan ini dirinci mulai dari tahap pembukaan, inti dan penutup.

Produk yang dikembangkan oleh peneliti adalah panduan teknik sosiodrama untuk meningkatkan kepercayaan diri. Keberterimaan isi materi, media panduan dinilai oleh satu ahli materi dan satu ahli media, secara teoritis berdasarkan kriteria akseptabilitas yaitu ketepatan, kegunaan, kemudahan, dan kemenarikan. Hasil penilaian dari ahli materi bimbingan dan konseling, ahli media dan calon pengguna berupa data angka dan data verbal. Data angka dan data verbal didapatkan atas pengisian instrumen ahli konseling dan diinterpretasi berdasarkan kategori yaitu panduan teknik sosiodrama ini dinilai berdasarkan aspek kegunaan, ketepatan, kemudahan, dan kemenarikan. Data angka hasil penilaian ahli materi menunjukkan presentase validitas ahli $88,75 \%$, penilaian uji ahli media menjukkan indeks presentase $96,59 \%$, dan penilaian uji calon pengguna menujukkan indeks presentase 96,59 \% yang masuk dalam kategori sangat tinggi. Penilaian angka tersebut menunjukkan bahwa panduan teknik sosiodrama yang dikembangkan sesuai dengan kriteria dan memenuhi keberterimaan dalam aspek kegunaan, ketepatan, kemudahan,dan kemenarikan. Selain itu data kualitatif dari uji ahli menunjukkan ada beberapa perbaikan agar panduan teknik sosiodrama dapat sangat berguna untuk membantu guru BK dalam memberikan layanan bimbingan di sekolah.

Berdasarkan uraian di atas, dapat disimpulkan bahwa proptype panduan teknik sosiodrama untuk meningkatkan kepercayaan diri siswa MTs sangat berterima sebagai panduan konseling teknik sosiodrama yang digunakan di sekolah baik secara teoritis maupun praktis dari aspek ketepatan, kegunaan, kemudahan dan kemenarikan.

Terdapat beberapa penelitian pengembangan yang pernah dilakukan sebelumnya untuk mengintervensi kepercayaan diri. Penelitian oleh Yuono (2015) melakukan penelitian dan pengembangan tentang media permainan monopoli untuk meningkatkan kepercayaan diri di SMP Negeri 1 Wonoayu. Kelemahan produk dari pengembangan ini adalah pemain dalam permainan monopoli ini terbatas hanya sampai 4-5 anak. Fatimah (2015) melakukan penelitian dan pengembangan model bimbingan kelompok dengan teknik role playing untuk mengembangkan kepercayaan diri siswa. Kelemahan produk ini adalah teknik yang digunakan masih belum spesifik. Tristy (2015) melakukan penelitian dan pengembangan media permainan congklak untuk meningkatkan kepercayaan diri. Kelemahan dalam penelitian ini adalah pemain dalam permainan ini terbatas hanya 2 orang dan bergantian yang akan memakan waktu banyak.

Berdasarkan beberapa paparan di atas dapat diketahui bahwa pengembangan yang sudah dilakukan memiliki kekurangan, oleh karena itu peneliti ingin mengembangkan produk panduan bimbingan yang diharapkan dapat menjawab kekurangan pada produk sebelumnya. Teknik sosiodrama dirasa mampu untuk meningkatkan kepercayaan diri karena sosiodrama dapat lebih mengekspresikan emosi dalam dirinya dan dapat lebih memahami 
dirinya dalam perannya. Jadi, peneliti mengembangkan produk yang berjudul Pengembangan Panduan Teknik Sosiodrama Untuk Meningkatkan Kepercayaan Diri siswa MTs Nurul Ulum

Kefektifan teknik sosiodrama untuk meningkatkan kepercayaan diri dapat dilihat dari penelitian sebelumnya yang pernah dilakukan oleh Dewi (2016) tentang efektivitas teknik sosiodrama untuk meningkatkan percaya diri siswa kelas VII B SMP Negeri 15 Malang. Selanjutnya penelitian oleh Prisnawati (2016) bahwa teknik sosiodrama efektif untuk meningkatkan kepercayaan diri siswa. Hasil dari kedua penelitian ini teknik sosiodrama efektif untuk meningkatkan kepercayaan diri. bahwa teknik sosiodrama efektif untuk meningkatkan kepercayaan diri siswa. Dari beberapa penjelasan yang sudah dijelaskan, dapat disimpulkan bahwa teknik sosiodrama dalam bimbingan klasikal efektif untuk meningkatkan kepercayaan diri siswa. Melalui teknik sosiodrama seseorang akan memahami masalah yang sebelumnya tidak disadari dan akan mengetahui cara untuk mengatasi salah dengan kata lain sosiodrama efektif untuk menjadikan seseorang lebih memiliki kepercayaan diri.

\section{Simpulan}

Penelitian dan pengembangan ini menghasilkan panduan teknik sosiodramauntuk meningkatkan kepercayaan diri siswa MTs yang tervalidasi oleh uji ahli materi, materi dan calon pengguna serta memenuhi akseptabilitas kegunaan, ketepatan, kemudahan dan kemenarikan. Berdasarkan uji ahli yang dilakukan diperoleh data angka hasil penilaian ahli materi menunjukkan presentase validitas ahli $88,75 \%$, penilaian uji ahli media menjukkan indeks presentase $96,59 \%$, dan penilaian uji calon pengguna menujukkan indeks presentase 96,59 \%yang masuk dalam kategori sangat tinggi. artinya sangat layak. Dengan demikian produk panduan teknik sosiodrama untuk meingkatkan kepercayaan diri siswa MTs yang dikembangkan layak digunakan oleh guru BK untuk memberikan layanan teknik sosiodrama di sekolah.

\section{Daftar Rujukan}

Borg, W.R., \& Gall, M.D. (2003). Education Research and Introduction, fourth edition. New York: Longman

Dewi. (2016). Efektivitas Teknik Sosiodrama untuk Meningkatkan Percaya Diri Siswa kelas VII B SMP Negeri 15 Malang. Malang: Jurusan Bimbingan dan Konseling, Fakultas Ilmu Pendidikan, Univeritsas Negeri Malang.

Fatimah, D. (2015). Pengembangan Model Bimbingan Kelompok dengan Teknik Role Playing Untuk Mengembangkan Kepercayaan Diri Siswa. Semarang: Universitas Negeri Semarang.

Fatimah, E. (2010). Psikologi Perkembangan ( Psikologi Perkembangan Peserta Didik). Bandung: Pustaka Setia.

Feorentika, K. (2016). Keefektifan Self Intruction untuk Meningkatkan Kepercayaan Diri Siswa di SMP N 20 Malang. Malang: Jurusan Bimbingan dan Konseling, Fakultas Ilmu Pendidikan, Universitas Negeri Malang.

Ilangga, D. (2014). Hubungan Antara Kepercayaan Diri dengan Prestasi Belajar Siswa di SMP Bhakti Pertiwi. Bimbingan dan Konseling.

Lauster, P. (2002). Tes Kepribadian. Jakarta: Bumi Aksara.

Luxori, Y. (2004). Percaya Diri. Jakarta: Kahlifah.

Prisnawati, T. (2016). Upaya Guru Bimbingan dan Konseling dalam Meningkatkan Kepercayaan Diri Siswa dengan Teknik Sosiodrama Kelas VII B SMPN 1 Sentolo. Yogyakarta: Bimbingan dan Konseling PGRI Yogyakarta.

Rahmat, J. (2000). Psikologi Komunikasi. Bandung: Remaja Rosda Karya.

Rasuly, M. (2012). Hubungan Antara Tingkat Kepercayaan Diri dengan Keterampilan Diri dan Penerimaan Diri dengan Keterampilan Komunikasi Interpersonal Siswa Kelas XI SMKN Sekota Pamekasan . Malang: Jurusan Bimbingan dan Konseling, Fakultas Ilmu Pendidikan, Universitas Negeri Malang. 
Jurnal Pembelajaran, Bimbingan, dan Pengelolaan Pendidikan, 1(2), 2021, 141-147

Romlah, T. (2018). Teori dan praktek Bimbingan dan Kelompok. Malang: Universitas Negeri Malang.

Setyo, R. D. (2010). Keefektifan Metode Permainan Simulasi dalam Bimbingan Kelompok untuk Meningkatkan Kepercayaan Diri Siswa SMPN 3 Malang. Malang: Jurusan Bimbingan dan Konseling, Fakultas Ilmu Pendidikan, Universitas Negeri Malang.

Sholikhah, M. (2018). Keeefektifan Teknik Sinema Edukasi untuk Meningkatkan Kepercayaan Diri Siswa SMP. Malang: Jurusan Bimbingan dan Konseling, Fakultas Ilmu Pendidikan, Universitas Negeri Malang.

Sholikhah, R. (2018). Hubungan Natara Kesiapan Belajar dan Kepercayaan Diri dengan Prestasi Belajar Siswa Kelas XI SMAN 1 Sekaran Lamongan. Malang: Jurusan Bimbingan dan Konseling, Fakultas Ilmu Pendidikan, Universitas Negeri Malang.

Sutriani. (2015). Efektivitas Bimbingan Kelompok dengan Model Expreiental Learning untuk Meningkatkan Kepercayaan Diri Siswa Kelas VII MTs Ma'arif Almukarom Ponorogo. Malang: Jurusan Bimbingan dan Konseling, Fakultas Ilmu Pendidikan, Univeristas Negeri Malang.

Thantaway. (2005). Kamus Istilah Bimbingan dan Konseling . Yogyakarta: Kanisius.

Tristy, W. L. (2015). Pengembangan Media Permainan Congklak untuk Meningkatkan Kepercayaan Diri Siswa Sekolah Dasar. Malang: Universitas Negeri Malang.

Viani, P. (2017). Hubungan Kepercayaan Diri Siswa Kelas X SMA Negeri 1 Ponggok Kabupaten Blitar. Malang: Jurusan Bimbingan dan Konseling, Fakultas Ilmu Pendidikan, Universitas Negeri Malang.

Yuono, C. (2015). Pengembangan Media Pemainan Monopoli Percaya Diri Pada Siswa Kelas VIII SMP Negeri 1 Wonoayu. Surabaya: Universitas Negeri Surabaya. 